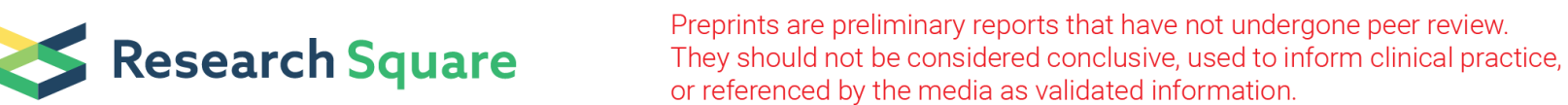

\section{The effect of combination of methanol with several concentration of honey solution on sperm quality of botia Chromobotia macracanthus Bleeker 1852 after short-term storage at $-80^{\circ} \mathrm{C}$}

Abinawanto Abinawanto ( $\square$ abinawanto.ms@sci.ui.ac.id )

Universitas Indonesia https://orcid.org/0000-0001-5540-1248

Siti Zuhriyyah Musthofa

Research Institute for Ornamental Fish Culture, Depok, West Java

Retno Lestari

Biology Department, Faculty of Mathematics and Natural Sciences, Universitas Indonesia, Depok 16424,West Java,

\section{Anom Bowolaksono}

Biology Department, Faculty of Mathematics and Natural Sciences, Universitas Indonesia, Depok 16424, West Java

\section{Martin Wilkes}

Centre for Agroecology, Water Resilience, Conventry University, United Kingdom

\section{Zainal Abidin Muchlisin}

Faculty of Marine and Fisheries, Syah Kuala University, Banda Aceh, Nanggro Aceh Darussalam

\section{Research article}

Keywords: Clown loach, Honey, Methanol, Ringer's solution, Spermatozoa preservation

Posted Date: November 14th, 2019

DOI: https://doi.org/10.21203/rs.2.17253/v1

License: (a) This work is licensed under a Creative Commons Attribution 4.0 International License. Read Full License 


\section{Abstract}

Background: Clown loach or botia, Chromobotia macracanthus Bleeker 1852, is a popular freshwater ornamental fish. Lack of high quality broodstock and asynchronous gonad maturation are the main problem in breeding of this species. Cryopreservation is one of the methods to overcome this problem, and cryoprotectant plays a vital role in this process. Herein, we tested two types of cryoprotectants, namely methanol as a permeating cryoprotectant and honey solution as a natural non-permeating cryoprotectant. Hence, the objective of the present study was to determine best combination of honey solution and methanol for short-term storage of $\mathrm{C}$. macracanthus sperm.

Methods: One level of methanol (10\%) combined with six levels of honey solution $(0 \%, 0.1 \%, 0.3 \%, 0.5 \%$, $0.7 \%$ and $0.9 \%$ ) were tested in this study. Ringer's solution was used as an extender. The diluted sperms were equilibrated for $25 \mathrm{~min}$ at $4{ }^{\circ} \mathrm{C}$ and then kept at $-80{ }^{\circ} \mathrm{C}$ for $48 \mathrm{~h}$. Sperms was thawed for $13 \mathrm{~s}$ at 40 ${ }^{\circ} \mathrm{C}$. Spermatozoa viability, motility, and fertilization rates were then observed.

Results: The one-way ANOVA showed that combination of methanol with several concentrations of honey had a significant effect on sperm viability and fertilization rates $(P<0.05)$, but did have a significant effect on sperm motility $(P>0.05)$. The study revealed that the $0.1 \%$ honey solution combined with $10 \%$ methanol resulted in the highest rates of motility $(89.4 \pm 5.45 \%)$, viability $(85.75 \pm 4.79 \%)$, and fertilization (98.55 $\pm 1.69 \%)$.

Conclusion: A $0.1 \%$ honey solution combined with $10 \%$ methanol in Ringer's was the best cryoprotectant for C. macracanthus spermatozoa preserved at $-80^{\circ} \mathrm{C}$.

\section{Introduction}

Botia Chromobotia macrachanthus Bleeker 1852 is a popular ornamental freshwater fish originating from Sumatera and Borneo, Indonesia [1], and this is one of the sumptuous most popular aquarium fish in Indonesia. The wild botia has been intensively harvested over the years resulting in decreasing populations in the habitat [2-6]. Besides, the habitat degradation associated with illegal logging is also threatening botia fish populations [3,4,7-14]. Fortunately, the bioecology of the botia has been well documented [2,5,15-19], and also the breeding technology of botia has been developed successfully $[2,18,20-25]$, and therefore currently, the supply has been swift from wild population to aquaculture production to meet the market demand.

However, botia hatcheries are still experiencing some obstacles, especially in developing high-quality broodstocks. This is because of long-lived gonad maturation and unsynchronized male and female gonad maturation $[2,20,22,24]$. Therefore, sperm cryopreservation is one of the potential solutions to overcome this problem [26-36]. According to Tsai and Lin [37], cryopreservation is a cell-storage technique that employs very low temperatures to maintain cell structure over time. 
Several species of fish sperm have been successfully cryopreserved, for instance bagrid catfish Mystus nemurus [26,38], African catfish Clarias gariepinus [35,39-43], giant goramy Osphronemus goramy [44,45], lampam Barbonymus gonionotus [46,47], salmonid spermatozoa [48-52], common carp Cyprinus carpio [53-58], zebra fish, Danio rerio [59-63] Mozambique tilapia, Sarotherodon mossambicus [64,65], rainbow trout, Oncorhynchus mykiss [66-71], and seurukan Osteochillus vittatus [72]. However, cryopreservation of botia sperm has never been reported previously.

Cryoprotectants are among the factors that contribute to the success of cryopreservation program $[27,35-37,43,73,74]$. This is because cryoprotectants can protect spermatozoa from cold and heat shocks $[27,35-37,43,71,73,74]$. However, at high concentration cryoprotectants are toxic to cellular systems including spermatozoa $[35,37,38,75-77]$. Therefore, a non-toxic cryoprotectant is critical for the cryopreservation process $[35,37,73,78,79]$. In general, there are two types of cryoprotectant, namely permeating (intracellular) and non-permeating (extracellular) cryoprotectants. Several studies showed that the simultaneously used of both cryoprotectants types gave a better results. For instance, Abinawanto et al. $[47,80]$ used a combination of skimmed milk and methanol for Java Barbs, Barbonymous gonionotus, sucrose and methanol for Indonesian Giant Goramy, Osphronemus goramy [44], honey solution, and Dimethyl Sulfoxide (DMSO) for Indonesian Giant Goramy, Osphronemus goramy and Indonesian shark minnow, Osteochillis hasseltii [45,81], and egg yolk and DMSO for depik, Rasbora tawarensis sperm [72]. In this study we tested the combination of honey solution as a natural nonpermeating cryoprotectant and methanol as a permeating cryoprotectants with Ringer's solution as an extender. These materials have been successful in cryopreserving 0 . goramy spermatozoa [45,82], but for botia spermatozoa they have not been evaluated previously. Therefore, the objective of the present study was to determine the best concentration of honey solution combined with $10 \%$ methanol for botia spermatozoa storage at $-80^{\circ} \mathrm{C}$.

\section{Materials And Methods}

\section{Time, site and Broodfish preparation}

The study was conducted from February 2017 to January 2018, at the hatchery of Research Institute for Ornamental Fish Culture, Depok, West Java Province, Indonesia. Forty mature males of botia with total body weight of $40-80 \mathrm{~g}$ were acclimated to laboratory conditions and fed on a commercial diet in $45 \times 30 \times 30 \mathrm{~cm}$ plastic containers for 15 days. Then the fish were grouped into four groups with average initial weights of $60.47 \pm 10.34 \mathrm{~g}$, and stocked in six plastic containers $(45 \times 30 \times 30 \mathrm{~cm})$. Each box was equipped with continuous aeration and a black plastic mesh lid to minimize disturbance and prevent fish from jumping out. Six experimental groups were assigned to four replicates in a completely randomised design. Fish were fed once daily to satiation at 09:00 AM.

\section{Ethical approval}


Health Research Ethics Committee Faculty of Medicine Univerity of Indonesia Cipto Mangunkusumo Hospital approved the study. Ethical approval number: KET919/UN2.F1/ETIK/PPM.00.02/2019

\section{Preparation extender and cryoprotectant}

The Ringer's solution and honey were used as extender and cryoprotectant, respectively. A stock of Ringers solution was prepared by dissolving $3.25 \mathrm{~g} \mathrm{NaCl} ; 0.125 \mathrm{~g} \mathrm{KCl} ; 0.175 \mathrm{~g} \mathrm{CaCl}_{2} .2 \mathrm{H}_{2} \mathrm{O}$; and $0.1 \mathrm{~g}$ $\mathrm{NaHCO}_{3}$ in distilled water up to $500 \mathrm{ml}$, and the solution was kept at $4{ }^{\circ} \mathrm{C}$ [45]. The pure honey was purchased from local market. Six concentrations of honey were tested, namely $0.1 \%, 0.3 \%, 0.5 \%, 0.7 \%$, and $0.9 \%$, for these purposes, the respective volume of honey of $0,0.1,0.3,0.5,0.7$, and $0.9 \mathrm{ml}$ were added into Fish Ringer's solution up to $100 \mathrm{ml}$ [45].

\section{Preparation of activator and eosin-Y solutions}

The activator solution was prepared by diluting $0.263 \mathrm{~g} \mathrm{NaCl} ; 0.037 \mathrm{~g} \mathrm{KCl}$ and $0.363 \mathrm{~g}$ Tris- $\mathrm{HCl}$ with aquabidest up to $100 \mathrm{ml}$. The solution was kept at $4{ }^{\circ} \mathrm{C}$ prior to use in the experiment [83]. The $0.5 \%$ of eosin-Y solution was prepared by diluting $0.5 \mathrm{~g}$ of the eosin- $Y$ with distilled aquabidest up to $100 \mathrm{ml}$.

\section{Sperm collection}

Four males weighing $60.47 \pm 10.34 \mathrm{~g}$ were treated intramuscularly with Ovaprim (Syndel Laboratories Ltd. Nanaimo, Canada) at dosage of $0.2 \mathrm{ml} \mathrm{kg}^{-1}$ body weight. After $18 \mathrm{~h}$, sperms were collected from individual male donors by a gentle abdominal stripping method [39] and placed in $2 \mathrm{~mL}$ vials (Cryogenic storage vial, Nalgene Nunc International).

\section{Sperm dilution}

Fresh sperm was suspended in the diluent mixtures containing Ringers solution, $10 \%$ methanol, and the respective honey solution where applicable (Table 1). The composition of the solution was modified from [45]. The dilution ratio of the fresh sperm and diluent solution was 1:9 based on Sunarma et al. [81]. The compositions of each component of the diluent solution and the ejaculated sperm are presented in Table 1. 


\section{Equilibration, freezing and thawing}

The diluted sperm was equilibrated at $4-5^{\circ} \mathrm{C}$ in an ice box for $15 \mathrm{~min}$ then frozen at $-80{ }^{\circ} \mathrm{C}$ in freezer for $48 \mathrm{~h}$. Thereafter, the frozen sperm was thawed at $40^{\circ} \mathrm{C}$ for $10 \mathrm{~min}$ in a water batch [45].

\section{Sperm quality evaluation.}

The fresh sperm was evaluated for colour and $\mathrm{pH}$. The preserved sperm was analyzed for motility, viability, and abnormality rates using a Boeco Trinocular Microscope (Boeco, Germany) equipped with a digital eyepiece camera (MDCE-5a). The microscope was connected to a computer equipped with an image driving software (Scopephoto 2.0.4).

\section{Egg Collection fertilization}

The eggs were collected from the mature female by gentle abdominal pressure then put in the plastic basin and kept at $5{ }^{\circ} \mathrm{C}$ prior to use for fertilization. A total of $2 \mathrm{ml}$ of eggs were mixed with $0.6 \mathrm{ml}$ of thawed sperm $(1: 3 \mathrm{v} / \mathrm{v})$ and two drops of tap water was added then mixed with a soft feather and left in contact for $5 \mathrm{~min}$. A total of 100 eggs were taken randomly and incubated in a plastic basin. The fertilization rate was observed two hours after incubation. The fertilized egg was transparent, while the unfertilized egg was opaque. The fertilization rate was calculated using the following formula: Fertilization rate $(\%)=$ Fertilized eggs/ Total number of incubated eggs $x 100$ [75].

\section{Statistical Analysis}

The percentage data were arcsine transformed prior to analysis [26]. The data of sperm motility, viability and fertilization were analyzed using one-way ANOVA then followed by the Duncan's multiple range test to determine the best treatment. The analysis was conducted using SPSS 14. (SPSS, Chicago, IL, USA). The qualitative data such as semen color, volume, $\mathrm{pH}$, and spermatozoa abnormality were analyzed descriptively.

\section{Results}

The fresh sperm was milky white, and $\mathrm{pH}$ was 7.9 (Table 2). The average diameter of the spermatozoa head was $3.5 \mu \mathrm{m}$, and the mean spermatozoa tail length was $32.81 \mu \mathrm{m}$. Viable sperm showed a green colour on the sperm head (Fig. 1a, Fig. 1b), whereas the non-viable sperm showed a pink or red colour on the sperm head (Fig. 1dc). In general, the quality of fresh sperm was higher than cryopreserved sperm. The motility, viability, and fertilization rates of fresh sperm were $97.75 \pm 2.63 \%, 83 \pm 2.45 \%$, and $100 \pm 0.0 \%$, respectively. However, the sperm quality was decreased gradually depending on the honey solution 
concentration after $48 \mathrm{~h}$ preservation. The ANOVA test showed that the application of honey solution in the diluent gave the significant effect on the sperm viability and fertilization rates $(P<0.05)$, but did not give a significant effect on the sperm motility $(P>0.05)$.

In general, the sperm quality was decreased with increases of honey solution concentrations. The Duncan's multiple range test showed that the higher sperm motility was found at $0.1 \%$ honey solution $(89.4 \pm 5.45 \%)$, but it was not different significantly with other treatments. The higher sperm viability was also recorded at $0.1 \%$ honey solution $(85.75 \pm 4.78)$, and this value was significantly higher than other treatments except the control $(74.5 \pm 7.89)$. In addition, the higher fertilization rate was recorded at the $0.1 \%$ honey solution, and this value was significantly higher that for honey concentrations of $0.5 \%, 0.7 \%$ and $0.9 \%$, but not significantly different to the different to the $0.3 \%$ treatment and the control (Table 2 ).

\section{Discussion}

The application of $0.1 \%$ honey with $10 \%$ methanol in the Ringer's solution gave the best results on spermatozoa quality of botia $48 \mathrm{~h}$ after freezing. The study revealed that sperm quality in the control (without honey) was lower than in the $0.1 \%$ honey treatment. However, the quality of cryopreserved sperm decreased gradually with higher concentrations of honey above $0.1 \%$. This is might be due to an increase viscosity of diluent when honey concentration was increased [84], and thereby preventing methanol entering the cell thereby reducing the protective effect of this permeating cryoprotectant inside the cell. Honey is known as natural non-permeating cryoprotectant. In general, the natural cryoprotectants are less toxic, inexpensive, and environmentally friendly $[35,43]$. Therefore, utilization of natural cryoprotectants as alternatives is highly recommended; however, it must be applied at the optimum concentration as recorded in this study.

The sperm motility rate in the best treatment ( $10 \%$ methanol $+0.1 \%$ honey) of this study is higher than others investigating combinations of cryoprotectants, such as the combinations of $20 \%$ skim milk $+5 \%$ methanol, $83.23 \%$ motility [47], $0.5 \%$ sucrose $+10 \%$ methanol, $81.62 \%$ motility [44], $15 \%$ skim milk $+10 \%$ methanol, $80.98 \%$ motility [80], $0.7 \%$ honey solution $+10 \%$ DMSO, $80.48 \%$ motility [45], DMSO + honey solution, $63.33 \%$ motility [81] and DMSO + Fish Ringer's solution, $58 \%$ motility $[26,85]$. Therefore, we assumed that the combination of methanol and honey at concentration of $10 \%$ and $0.1 \%$ is an effective cryoprotectant to maintain sperm quality of botia during cryopreservation.

In the present study, honey solution was applied as a non-permeating cryoprotectant, while methanol as a permeating cryoprotectant. The simultaneous application of both permeating and non-permeating cryoprotectants resulted in better cryoprotective effect because these cryoprotectants gave complementary effect outside and inside of the cells [85]. Besides being effective for botia sperm as recorded in this present study, the combination of methanol and honey have been successfully applied in several others species, for example in tropical bagrid catfish sperm Mystus nemurus [26], African catfish Clarias gariepinus [35], and Indonesian shark minnow, Osteochilus hasseltii Valenciennes, 1842 [81]. Although using the same combination of the materials, we found that the motility rate of the botia sperm 
after cryopreservation was higher compared to previous studies in $M$. nemurus, Osphronemus goramy, and $O$. hasseltii $[26,45,81]$. Indeed, the fertilization rate in this present study was also higher than in $C$. gariepinus [35], B. gonionotus [47], O. goramy [45], Oreochromis mossambicus [63], O. hasseltii [81,24], Mystus nemurus [26], C. carpio [85], and Lota lota [51].

\section{Conclusion}

It is concluded that the combination of $0.1 \%$ of honey and $10 \%$ methanol are effective as cryoprotectant agents for botia fish Chromobotia macrachanthus sperm storage at $-80{ }^{\circ} \mathrm{C}$ for $48 \mathrm{~h}$.

\section{Declarations}

\section{Declaration for ethical approval}

We would like to declare that the study was approved by the Health Research Ethics Committee Faculty of Medicine Univerity of Indonesia Cipto Mangunkusumo Hospital which Ethical approval number: KET919/UN2.F1/ETIK/PPM.00.02/2019

\section{Consent for publication}

We would like to confirm that all of authors have approved the manuscript for submission

\section{Availability of data and materials}

We would like to declare that neither the manuscript nor any part of its content are currently under consideration or published in another journal, and no material submitted as part of a manuscript infringes existing copyrights, or the rights of a third party.

\section{Competing interests}

We would like to declare that we have no competing interest.

\section{Funding}

This research was funded by Universitas Indonesia Competitive Research Grant with Contract No. 609/UN2.R3.1/HKP.05.00/2017.

\section{Author's contributor}

Abinawanto Abinawanto ( $\mathrm{ABI}$ ) was a major contributor in writing the manuscript. Siti Zuhriyah Mustopha (SZM) analyzed and interpreted the sperm motility and sperm viability before and after freezing. Retno Lestari (RLE) performed the sperm abnormality examination before and after freezing. Anom 
Bowolaksono (ABO) evaluated fertization rate before and after freezing. Martin Wilkes (MW) making English correction and proofreading the manuscript. Zainal Abidin Muchlisin (ZAM) read, critized and providing the supporting data to the manuscript. All authors read and approved the final manuscript.

\section{Acknowledgements}

This study was supported by a research grant from Universitas Indonesia with Contract No. 609/UN2.R3.1/HKP.05.00/2017. Special thanks to Taryana and Asri Martini for their kind assistance.

\section{Author's detail}

${ }^{1}$ Abinawanto Abinawanto from Biology Department, Faculty of Mathematics and Natural Science, Universitas Indonesia, Depok Campus, Depok 16424, West Java, Indonesia

${ }^{2}$ Siti Z. Mustopha from Research Institute for Ornamental Fish Culture, Depok, West Java, Indonesia

${ }^{1}$ Retno Lestari from Biology Department, Faculty of Mathematics and Natural Science, Universitas Indonesia, Depok Campus, Depok 16424, West Java, Indonesia

${ }^{1}$ Anom Bowolaksono from Biology Department, Faculty of Mathematics and Natural Science, Universitas Indonesia, Depok Campus, Depok 16424, West Java, Indonesia

${ }^{3}$ Martin Wilkes from Centre for Agroecology, Water and Resilience, Coventry University, United Kingdom, CV8 3LG

${ }^{4}$ Zainal A. Muchlisin from Faculty of Marine and Fisheries, Syah Kuala University, Banda Aceh, Provinsi Aceh Indonesia.

\section{References}

1. Kottelat, M., Whitten, A.J., Kartikasari, S.N., Wirjoatmodjo, S. : Freshwater Fishes of Western Indonesia and Sulawesi. Jakarta: Periplusedn. Ltd.; Hongkong (1996) 2. Legendre, M., Satyani, D., Subandiyah, S., Sudarto, Pouyaud, L., Baras, E., Slembrouck, J.: Biology and culture of the clown loach Chromobotia macracanthus (Cypriniformes, Cobitidae): 1-Hormonal induced breeding, unusual latency response and egg production in two populations from Sumatra and Borneo Islands. Aquatic Liv Res 25, 95-108 (2012) 3. Hossain, Md. Y., Hossen, Md. A., Ahmed, Z. F., Yahya, K., Rahman, Md. M., Ahmed, F., Ohtomi, J.: Threatened fishes of the world: Botia dario (Hamilton, 1822) (Cypriniformes: Cobitidae). Croatian J Fish 73, 86 - 88 (2015) 4. Hossen, Md. A., Hossain, Md. Y., Pramanik, Md. N. U., Nawer, F., Khatun, D., Parvin, M. F., Rahman, Md. M.: Morphological characters of Botia lohachata. J. Coastal Life Med 4(9), 689-692 (2016) 5. Hossain, Md. Y., Hossen, Md. A., Pramanik, Md. N. U., Nawer, F., Rahman, Md. M., Sarmin, S., Khatun, D., Bahkali, A. H., Ergoban, A. M., Yahya, K.: Life-History Traits of the Endangered Carp Botia dario 
(Cyprinidae) from the Ganges River in Northwestern Bangladesh. Pakistan J Zool 49(3), 801-809 (2017) 6. Ng, P. K. L., Tan, H. H. Freshwater fishes of Southeast Asia: potential for the aquarium fish trade and conservation issues. Aquarium Sci Conserv 1, 79-90 (1997) 7. Onrizal, Kusmana, C., Saharjo, B. H. Handayani, I. P., Kato, P.: Social Environmental Issues of Danau Sentarum National Park, West Kalimantan. Biodiv 6(3), 220-223 (2005) 8. Gupta, N., Sivakumar, K., Mathur, V.B., Chadwick, M.A.: Terrestrial protected areas and managed reaches conserve threatened freshwater fish in Uttarakhand, India. Parks J 21(1), 89-101 (2015) 9. Raghavan, R., Dahanukar, N., Tlusty, M., Rhyne, A., Kumar, K., Molur, S., Rosser, AM.: Uncovering an obscure trade: Threatened freshwater fishes and the aquarium pet markets. Biol Conserv 164, 158-169 (2013) 10. Tlusty, M. F., Dowd, S., Raghavan, P. R.: Saving forest through fisheries - ornamental fisheries as means to avoid deforestation. OFI J 56, 21-25 (2008) 11. Islam, Md.A., Asif, A. Al, Samad, Md.A., Sarker, B., Ahmed, M., Abdus Satter, M.A., Hossain, A. A. : Comparative study on fish biodiversity with conservation measures of the Bhairabriver, Jessore, Bangladesh. Asian J Med Biol Res 3(3), 357-367 (2017) 12. Lakra, W.S., Sarkar, U.K., Kumar, R.S., Pandey, A., Dubey, P.K., Om Prakash Gusain, O.P.: Fish diversity, habitat ecology and their conservation and management issues of a tropical River in Ganga basin, India. The Environment 30(4):306-319 (2010) 13. Indonesian Biodiversity Strategy and Action Plan (IBSAP): National document. National Development Planning Agency (Bappenas), Indonesia, 160 pp (2003) 14. Afrose, S., Ahmed, N.: Effect of Degraded Ecosystem on Fish Biodiversity in the Old Brahmaputra River, Bangladesh and Its Conservation Measures. IOSR Journal of Environmental Science, Toxicology and Food Technology (IOSR-JESTFT) 10(9), 37-43 (2016) 15. Tan, H.H., Kottelat, M.: The fishes of the Batang Hari drainage, Sumatra, with description of six new species. Ichthyol. Explor. Freshwaters 20(1),13-69 (2009) 16. Kottelat, M.: The fishes of the inland waters of southeast asia: a catalogue and core bibliography of the fishes known to occur in freshwaters, mangroves and estuaries. The Raffles Bull Suppl Zool 27, 1-663 (2013) 17. Gupta, G.: A note on the biology of necktie loach, Botia dario (Hamilton, 1822). Int'l J Res Fish Aquacult 6(1), 1-3 (2016) 18. Dey, A., Barat, S.: Spawning biology and captive breeding of vulnerable loach Botia histrionica (Blyth) in Cooch Behar, West Bengal, India. J Exp Biol 5(10), $46-48$ (2015) 19. Dey, A., Sarkar, D., Barat, S.: Spawning biology, embryonic development and captive breeding of vulnerable loach Botia dario (Hamilton). J Entomol Zool Stud 3,183-8 (2015) 20. Musthofa, S. Z., Wulandari, R., Abinawanto, A.: Spawning biology and fertility of Clown Loach (Chromobotia macracanthus Bleeker 1852) in captivity. Proceeding 3rd Int Symp Curr Progress in Math and Sci doi: 10.1063/1.5064150: 4 pp. (2018) 21. Mercy, T. V. A., Sajan, S., Malika, V.: Captive breeding and developmental biology of Sahyadria denisonii (Day 1865) (Cyprinidae), an endangered fish of the Western Ghats, India, Indian J Fish 62(2), 19-28 (2015) 22. Permana, A., Alimuddin, Hadi, W., Priyadi, A.: Growth response of clown loach (Chromobotia macracanthus Bleeker 1852) juveniles immersed in water containing recombinant growth hormone. Indonesian Aquacult $J$ 10(2),125-130 (2015) 23. Kang, Xu, Duan Wei, Xiao Jun, Tao Min, Zhang Chun, Liu Yun, Liu Shaojun.: Development and application of biological technologies in fish genetic breeding. Sci China Life Sci 58(2),1-15 (2014) 24. Putra, H.F.E., Sugianto, S., Rahardjo, P., Permana, A.: The artificially spawning of botia fish (Chromobotia macracanthus Bleeker) with HCG (Human Chorionoc Gonadothropin) and LHRHa (Luteinizing Hormone Releasing Hormone Analog) injection. J Aquacult Fish Health 6(3), 101-106 (2017) 25. Haque, S., Biswas, S.P.: Some aspects of reproductive biology of Botia dario (Hamilton- 
buchanan) from Sivasagar District, India. Int J Curr Aca Rev 2(12), 71-77 (2014) 26. Muchlisin, Z.A. Hashim, R. A.S.C. Chong, A.S.C.: Preliminary study on the cryopreservation of tropical bagrid catfish (Mystus nemurus) spermatozoa; the effect of extender and cryoprotectant on the motility after short-term storage. Theriogenol 62, 25-34 (2004) 27. Chew, C., Zulkafli, A.R.: Sperm cryopreservation of some freshwater fish spesies in Malaysia. In: Igor I. Katkov, editor. Current Frontiers in Cryopreservation. Intech, 269-93 (2012) 28. Cabrita, E., Sarasquete, C., Martines-Paramo, S., Robles, V., Beirao, J., Peres-Carezales, S., Herraes, P.: Cryopreservation of fish sperm: Applications and perspectives. J App Ichthyol 26(5), 623635 (2010) 29. Yang, H., Tiersch, T.R.: Current Status of Sperm Cryopreservation in Biomedical Research Fish Models: Zebrafish, Medaka, and Xiphophorus. Comp Biochem Physiol C Toxicol Pharmacol 149(2), 224-232 (2009) 30. Riesco, M.F., Oliveira, C., Soares, F., Gavaia, P.J., Dinis, M.T., Cabrita. E.: Solea senegalensis sperm cryopreservation: New insights on sperm quality. PLoS One 12(10), 1-19 (2017) 31. Jang, T.H., Park, S.C., Yang, J.H., Kim, J.Y., Seok, J.H., Park, U.S., Choi, C.W., Lee, S.R., Han, J.: Cryopreservation and its clinical applications. Integr Med Res 6, $12-18$ (2017) 32. Martínez-Páramoa, S. Horváth, A., Labbéc, C., Zhangd, T., Roblese, V., Herráezf, P., Suquet, M., Adams, S., Viveiros, A., Tiersch, T.R., Cabrita, E.: Cryobanking of aquatic species. Aquacult 472, 156-177 (2017) 33. Hezavehei, M., Mohsen, S., M., Kouchesfahani, H.M., Henkel, R., Agarwal, A., Esmaeili, V., Shahverdi, A.: Sperm cryopreservation: A review on current molecular cryobiology and advanced approaches. RBMO 37(3), 327-339 (2018) 34. Tiersch, T. R.: Strategies for commercialization of cryopreserved fish semen. R. Bras. Zootec. suplemento especial 37, 1-19 (2008) 35. Muchlisin, Z. A., Nadiah, W. N., Nadiya, N., Fadli, N., Hendri, A., Khalil, M., Siti-Azizah, M. N.: Exploration of natural cryoprotectans for cryopreservation of African catfish, Clarias gariepinus, Burchell 182 (Pisces: Clariidae) spermatozoa. Czech J Anim Sci 60(1), 10-15 (2015) 36. Agarwal, N.K. Cryopreservation of fish semen. Himalayan Aquatic Biodiv Conserv \& New Tools in Biotech 104-127 (2011) 37. Tsai S., Lin, C.: Advantages and applications of cryopreservation in fisheries science. Braz Arch Biol Technol 55, 425-34 (2012) 38. Muchlisin, Z.A., Siti-Azizah, M.N.: Influence of cryoprotectans on abnormality and motility of baung (Mystus nemurus) spermatozoa after long-term cryopreservation. Cryobiol 58, 166-9 (2009) 39. Muchlisin, Z. A., Nadiya, N., Nadiah, W. N., Musman, M., Siti-Azizah, M. N.: Preliminary study on the natural extenders for artificial breeding of African catfish Clarias gariepinus (Burchell, 1822). AACL Bioflux 3(2),119-124 (2010) 40. Omitogun, O.G., Olaniyan, O.G., Oyeleye, O.F., Ojiokpota, O.O., Aladele, C., Odofin, S.E., Odoflin, W.T.: Potentials of short term and long term cryopreserved sperm of the African giant catfish (Clarias gariepinus Burchell, 1822) for aquaculture. Afr J Biotechnol 9(41), 6973-6982 (2010) 41. Viveiros, A.T.M., So, N., Komen, J.: Sperm cryopreservation of African catfish, Clark garieninus: Cryoprotectants, freezing, and sperm dilution ratio. Theriogenol 54, 1395-I408 (2000) 42. Olanrewaju, A.N., Kareem, O.K., Orisasona, O.: Cryopreservation: A Viable Tool for Sustainable Catfish Aquaculture Industry in Nigeria. J Fisheries Livest Prod 3, 4 (2015) 43. Muchlisin, Z.A.: Current status of extenders and cryoprotectants on fish spermatozoa cryopreservation. Biodiv 6, 66-9 (2005) 44. Abinawanto, Nurman, K., Lestari, R.: The effect of sucrose on sperm quality of Goramy fish, Osphronemus goramy Lacepede, 1801 two days post- cryopreservation. J Agri Sci Tech B2, 204-207 (2012a) 45. Abinawanto, Pratiwi, I. A. Lestari, R.: Sperm motility of giant gourami (Osphronemus goramy, Lacepede, 1801) at several concentrations of honey combined with DMSO after short-term storage. AACL Bioflux 10(2), 156-163 (2017a) 46. Abinawanto, Rahayu, S., Lestari, R.: Cryopreservation of 
Java barb (Barbonymus gonionotus) spermatozoa using egg yolk as a cryoprotectant. Global Vet 10(3), 318-321 (2013) 47. Abinawanto, Zuraida, Lestari, R.: The effect of skim milk combined with $5 \%$ of metanol on motiliy, viability, and abnormality of Java barb, Barbonymus gonionotus spermatozoa after 24 hours freezing. AACL Bioflux 9(2), 326-333 (2016) 48. Harvey, B., Ashwood-Smith, M.J.: Cryoprotectant penetration and supercooling in the eggs of salmonid fishes. Cryobiol 19, $29-40$ (1982) 49. Negus, M.T.: Salmonid sperm cryopreservation techniques. Minnesota Department of Natural Resources. Division of Fish and Wildlife, Section of Fisheries. (2008) 50. Figueroa, E., Farias, J.G., Lee-Estevez, M., Valdebenito, I., Risopatrón, J., Magnotti, C., Romero, J., Watanabe, I. Oliveira, R.P.S.: Sperm cryopreservation with supplementation of a-tocopherol and ascorbic acid in freezing media increase sperm function and fertility rate in Atlantic salmon (Salmo salar). Aquacult 493,1-8 (2018) 51. Lahnsteiner, F., Mansour, N., Weismann, T.: The cryopreservation of spermatozoa of the burbot, Lota lota (Gadidae, Teleostei). Cryobiol 45, 195-203 (2002) 52. Figueroa, E., Valdebenito, I., Merino, O., Ubilla, A., Risopatrón, J., Farias, J. G.: Cryopreservation of Atlantic salmon Salmo salar sperm: effects on sperm physiology. J Fish Biol 89(3), 1537-1550 (2016) 53. Horvath, L., Miskolczi, E., Urbanyi, B.: Cryopreservation of common carp sperm. Aquat Living Resour 16, 457-60 (2003) 54. Withler, F.C.: Cryopreservation of spermatozoa of some freshwater fishes cultured in South and Southeast Asia. Aquacult 26, 395-8 (1982) 55. Bernáth, G., Bokor, Z., Żarski, D., Várkonyi, L., Hegyi, A., Staszny, A., Urbányi, B., Ifj, J.R., Horváth, A.: Commercial-scale out-ofseason cryopreservation of Eurasian perch (Perca fluviatilis) sperm and its application for fertilization. Anim. Repro. Sci. 170, 170-177 (2016) 56. Horvath, Á., Miskolczi, E., Mihálffy, S., Ősz, K., Szabó, K., Urbányi, B. : Cryopreservation of common carp (Cyprinus carpio) sperm in 1.2 and $5 \mathrm{ml}$ straws and occurrence of haploids among larvae produced with cryopreserved sperm. Cryobiol 54(3), 251-257 (2007) 57. Boryshpolets, S., Sochorová, D., Rodina, M., Linhart, O., Dzyuba, B.: Cryopreservation of carp (Cyprinus carpio L.) sperm: impact of seeding and freezing rates on post-thaw outputs. Biopreserv. Biobank 15(3), 234-240 (2017) 58. Magyary, I., Urbanyi, B., Horvath, L. Cryopreservation of common carp (Cyprinus carpio L.) sperm II. Optimal conditions for fertilization. J Appl Ichthyol 12(2), 117-119 (1996) 59. Harvey, B., Kelley, R.N., Ashwood-Smith, M.J. Cryopreservation of zebrafish spermatozoa using methanol. Can J Zool 60, 1867-70 (1982) 60. Draper, B.W. Moens, C.B.: A high-throughput method for zebrafish sperm cryopreservation and in vitro fertilization. JoVE 29, 1395 (2009) 61. Carmichael, C., Westerfield, M. Varga, Z.M.: Cryopreservation and in vitro fertilization at the zebrafish international resource center. In Zebrafish, 45-65. Humana Press. (2009) 62. Matthews, J.L., Murphy, J.M., Carmichael, C., Yang, H., Tiersch, T., Westerfield, M. Varga, Z.M.: Changes to extender, cryoprotective medium, and in vitro fertilization improve zebrafish sperm cryopreservation. Zebrafish 15(3), 279-290 (2018) 63. Rebocho, S.R.D.M.V.: Development of a new ultra-fast freezing procedure for zebrafish sperm cryopreservation (Doctoral dissertation). (2018). 64. Harvey, B.: Cryopreservation of Sarotherodon mossambicus spermatozoa. Aquacult; 32, 31320 (1983) 65. Ugwu, S.I., Kowalska, A., Morita, M., Kowalski, R.K.: Application of glucose-methanol extender to cryopreservation of Mozambique tilapia (Oreochromis mossambicus) sperm. Turkish J Fish Aquat Sci 19(1), 41-50 (2018) 66. Stoss, J., Donaldson, E.M.: Studies on Cryopreservation of eggs from rainbow trout (Salmo gairdneri) and coho salmon (Onchorchynchus kisutch). Aquacult 31, 51-65 (1983) 67. Kutluyer, F., Kayim, M., Öğretmen, F., Büyükleblebici, S. Tuncer, P.B.: Cryopreservation of rainbow trout Oncorhynchus mykiss spermatozoa: effects of extender supplemented with different antioxidants on 
sperm motility, velocity and fertility. Cryobiol 69(3), 462-466 (2014) 68. Robles, V., Cabrita, E., Cuñado, S., Herráez, M.P.: Sperm cryopreservation of sex-reversed rainbow trout (Oncorhynchus mykiss): parameters that affect its ability for freezing. Aquacult 224(1-4), 203-212 (2003) 69. Bozkurt, Y., Seçer, S., Tekin, N., Akçay, E.: Cryopreservation of rainbow trout (Oncorhynchus mykiss) and mirror carp (Cyprinus carpio) sperm with glucose based extender. Süleyman Demirel Üniversitesi Eğirdir Su Ürünleri Fakültesi Dergisi 1(1), 21-25 (2005) 70. Tekin, N., Secer, S., Akcay, E., Bozkurt, Y.: Cryopreservation of rainbow trout (Oncorhynchus mykiss) semen. (2003) 71. Ciereszko, A., Dietrich, G.J., Nynca, J., Dobosz, S., Zalewski, T.: Cryopreservation of rainbow trout semen using a glucose-methanol extender. Aquacult 420, 275-281 (2014) 72. Muthmainnah, C.R., Eriani, K., Hasri, I., Irham, M., Batubara, A.S. Muchlisin, Z.A.: Effect of glutathione on sperm quality after short-term cryopreservation in seurukan fish Osteochilus vittatus (Cyprinidae). Theriogenol 122, 30-34 (2018) 73. Anil, S., Ghafari. F., Zampolla, T., Rawson, D. M., Zhang, T.: Studies on cryoprotectant toxicity to zebrafish (Danio rerio) ovarian tissue fragment. Cryo Lett, 40-50 (2011) 74. Gil, H.W., Lee, T.H., Park, I.S.: Effects of Cryoprotectants and Diluents on the Cryopreservation of Spermatozoa from Far Eastern Catfish, Silurus asotus. Dev Repro 21(1), 71 (2017) 75. Anil, S.: Development of in-vitro culture and cryopreservation protocol for Zebrafish (Danio rerio) ovarian tissue fragments (2013). 76. Best, B.P.: Cryoprotectant toxicity: facts, issues, and questions. Rejuv. Res., 18(5), 422-436 (2015) 77. Sieme, H., Oldenhof, H., Wolkers, W. F.: Mode of action of cryoprotectants for sperm preservation. Anim Repro Sci 169, $2-5$ (2016) 78. Dash, S.N., Routray, P., Dash, C., Guru, B.C., Swain, P. Sarangi, N.: Use of the non-toxic cryoprotectant trehalose enhances recovery and function of fish embryonic stem cells following cryogenic storage. Curr Stem Cell Res Therapy 3(4), 277-287 (2008) 79. Szurek, E.A., Eroglu, A.: Comparison and avoidance of toxicity of penetrating cryoprotectants. Plos One 6(11), 27604 (2011) 80. Abinawanto, Anindita, l., Lestari, R.: Cryopreservation of spermatozoa of Osphronemus goramy fish using skim milk. Int J. Eng Innov Technol 2, 62-4 (2012b) 81. Sunarma, A., Hastuti, D.W., Sistina, Y.: Combination effect of honey with different cryoprotectant on spermatozoa of the Indonesian shark minnow, Osteochillus hasseltii Valenciennes, 1842] after cryopreservation. Proceeding Indonesian Aquacult. Conf. 2007, Surabaya, June 5-7, 2007. Indonesian Aquaculture Society, 1-9 (2007) 82. Abinawanto, A., Putri, P. E.: Goramy spermatozoa quality after sub-zero freezing: the role of coconut water as the cryoprotectant. Cell Biol Dev 1, 1-5 (2017b) 83. Perchec, G., Jeulin, C., Cosson, J., André, F., Billard, R.: Relationship between sperm ATP content and motility of carp spermatozoa. J Cell Sci 108, 747-53 (1995) 84. Sakri, F.M.: Honey and its efficacy: Healthy supplement without side effect. 1st Print. Diandra Indonesian Library, Yogyakarta, viii + 88 pp (2015) 85. Akcay, E., Bozkurt, Y., Secer, S., Tekin, N.: Cryopreservation of mirror carp semen. Turkish J Vet Anim Sci 28, 837-43 (2004)

\section{Tables}

Table 1. Composition of diluent used for cryopreservation of botia fish Chromobotia macrachanthus perm 


\begin{tabular}{lcccccc}
\hline Composition & \multicolumn{7}{c}{ Experimental group } \\
\cline { 2 - 7 } & $\mathrm{C}$ & H $0.1 \%$ & H 0.3\% & H 0.5\% & H 0.7\% & H 0.9\% \\
\hline Sperm $(\mu \mathrm{L})$ & 30 & 30 & 30 & 30 & 30 & 30 \\
\hline Methanol $(\mu \mathrm{L})$ & 30 & 30 & 30 & 30 & 30 & 30 \\
\hline Honey Solution $(\mu \mathrm{L})$ & 0 & 240 & 240 & 240 & 240 & 240 \\
\hline Fish Ringer $(\mu \mathrm{L})$ & 240 & 0 & 0 & 0 & 0 & 0 \\
\hline
\end{tabular}

$\mathrm{C}=$ Control, without honey solution; $\mathrm{H}$ 0.1-0.9\% = honey solution.

Table 2. Spermatozoa analyses of Botia's fish $48 \mathrm{~h}$ after freezing. Values are means \pm SD of four replicates. Mean values having the same superscript are not significantly different $(p>0.05)$.

\begin{tabular}{lccc}
\hline \multirow{2}{*}{ Experimental group } & \multicolumn{3}{c}{ Sperm Quality Parameters } \\
\cline { 2 - 4 } & Motility (\%) & Viability (\%) & Fertilization (\%) \\
\hline Fresh sperm & $97.75 \pm 2.63^{\mathrm{b}}$ & $83 \pm 2.45^{\mathrm{b}}$ & $100 \pm 0.0^{\mathrm{b}}$ \\
\hline 0\% (control) & $85.45 \pm 11.99^{\mathrm{a}}$ & $74.5 \pm 7.89^{\mathrm{ab}}$ & $91.61 \pm 10.29^{\mathrm{ab}}$ \\
\hline H 0.1\% & $89.4 \pm 5.45^{\mathrm{a}}$ & $85.75 \pm 4.78^{\mathrm{b}}$ & $98.55 \pm 1.69^{\mathrm{b}}$ \\
\hline H 0.3\% & $83.05 \pm 4.18^{\mathrm{a}}$ & $67 \pm 10.23^{\mathrm{a}}$ & $93.91 \pm 9.33^{\mathrm{ab}}$ \\
\hline H 0.5\% & $81.15 \pm 8.14^{\mathrm{a}}$ & $66.75 \pm 9.56^{\mathrm{a}}$ & $89.67 \pm 8.22^{\mathrm{a}}$ \\
\hline H 0.7\% & $81.9 \pm 7.05^{\mathrm{a}}$ & $66.5 \pm 14.07^{\mathrm{a}}$ & $84.46 \pm 10.22^{\mathrm{a}}$ \\
\hline H 0.9\% & $82.27 \pm 6.18^{\mathrm{a}}$ & $67 \pm 14.07^{\mathrm{a}}$ & $82.39 \pm 16.90^{\mathrm{a}}$ \\
\hline
\end{tabular}

\section{Figures}

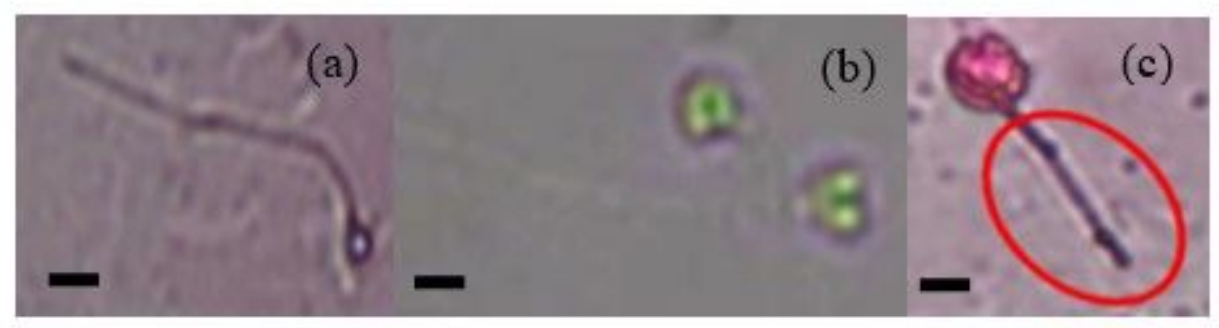


Viable sperm (a, b), and non-viable sperm (c). Magnification 1000X; Bar = 10 micrometer 